\title{
PEMBELAJARAN MATERI SISTEM PERIODIK UNSUR MENGGUNAKAN TGT (TEAM GAMES TOURNAMENT) BERBANTUKAN ALAT PERAGA TERHADAP HASIL BELAJAR DI KELAS X SMA UISU MEDAN
}

\section{PERIODIC SYSTEM LEARNING MATERIAL USING TGT (Team Games Tournament) ASSISTED WITH TEACHING AIDS ON LEARNING OUTCOMES IN CLASS X SMA UISU MEDAN}

\author{
Osnia*, Lisa Ariyanti Pohan, Adilah Wirdhani Lubis \\ Universitas Islam Sumatera Utara, Department of Chemistry Education, Medan 20217, \\ North Sumatera, Indonesia \\ *Corresponding author : osnia01@gmail.com
}

\begin{abstract}
ABSTRAK
Penelitian ini bertujuan untuk melihat perubahan belajar materi sistem periodik unsur menggunakan TGT (Team Games Tournament) berbantukan alat peraga terhadap hasil belajar Di Kelas X SMA UISU Medan. Penelitian ini dilaksanakan di SMAS UISU Medan dan dilaksanakan pada Agustus 2019 s/d September 2019. Populasi pada penelitian ini adalah seluruh siswa kelas X SMA UISU Medan Tahun Pelajaran 2018/2019 yang terdiri dari kelas IPA dan IPS sedangkan sampel yang digunakan adalah pada kelas IPA yang berjumlah 33 siswa. Metode penelitian yang digunakan dalam penelitian ini adalah Quasi Experimental. Analisis data dilakukan dengan menggunakan Microsoft Excel. Berdasarkan analisis data, hasil penelitian ini menunjukkan bahwa $\mathrm{t}_{\text {hitung }}$ sebesar 4,54 dan $\mathrm{t}_{\text {tabel }}$ sebesar 1,669 pada taraf signifikan $5 \%$ atau $\alpha=0,05$. Karena $t_{\text {hitung }}>t_{\text {tabel }}(4,54>1,669)$, maka hipotesis alternatif penelitian $\left(\mathrm{H}_{\mathrm{a}}\right)$ diterima yang berarti bahwa $\mathrm{Ha}$ : Terdapat pengaruh TGT (Team Games Tournament) dengan menggunakan alat peraga terhadap materi sistem periodik unsur. Maka Kesimpulan dalam penelitian ini adalah Pembelajaran Materi Sistem Periodik Unsur Berhasil Menggunakan TGT (Team Games Tournament) Berbantukan Alat Peraga Terhadap Hasil Belajar Di Kelas X SMA UISU Medan.
\end{abstract}

Kata kunci: Quasi Experiment, TGT (Team Games Tournament)

\section{ABSTRACT}

This study aims to look at the chage in learning periodic system elements using TGT (Team Games Tournament) assisted with teaching aids on learning outcomes in class x SMA UISU MEDAN. This research was conducted at SMA UISU MEDAN and carried out in August 2019 until September 2019. The population in this studi was all students of class IPA and IPS, while the sample used is in class IPA of 33 students. The research method used in this research is quas experiment. Data analysis was performed using mocrosoft exel. Based on 
data analysis, the results of this study indi cate that $T_{\text {COUNT IT }} O F$ 4, 54 And and table of 1,669 at a significant level $5 \%$ or $=0,05$. Because $T_{\text {count It }}>T_{\text {table }}(4,54,1,669)$ hance alternative research hypotheses ( $\mathrm{Ha}$ ) accepted meands $\mathrm{Ha}$ : accepted meands that $\mathrm{Ha}$ :there influence TGT (Team Games Tournament) by usingteaching aids on the material periodic learning system elements. Then the conclusion in this study is the periodic learning system elements. Of elements using success fully TGT (Team Games Tournament) assisted withb teaching aids an learning outcomes in class X SMA UISU MEDAN

Keywords: Quasi Experiment, TGT (Team Games Tournament)

\section{PENDAHULUAN}

Hasil belajar siswa pada beberapa materi pelajaran kimia belum memuaskan di SMA UISU Medan, salah satunya pada pokok bahasan Sistem Periodik Unsur. Menurut informasi seorang guru bidang studi kimia yang mengajar di SMA UISU Medan, khususnya kelas X mengalami kesulitan dalam mempelajari Sistem Periodik Unsur. Hal ini terlihat dari nilai rata-rata ulangan siswa pada pokok bahasan Sistem Periodik Unsur $<6,5$.

Rendahnya hasil belajar siswa pada pokok bahasan ini disebabkan karena siswa mengalami kesulitan dalam memahami, dan sementara itu pada umumnya guru menggunakan metode diskusi informasi, dimana siswa cenderung pasif sehingga siswa kurang termotivasi, kurang tekun dalam proses pembelajaran, timbulnya rasa bosan dan jenuh. Menurut Sudjana (2017:22) hasil belajar adalah kemampuan yang dimiliki siswa setelah menerima pengalaman belajar. Hasil dari kegiatan belajar ditandai dengan adanya perubahan perilaku ke arah positif yang relatif permanen pada diri orang yang belajar.

Untuk itu diperlukan suatu strategi pembelajaran yang dapat meningkatkan aktivitas belajar siswa. Rasa bosan dan jenuh dapat terjadi karena guru hanya menyajikan materi dan tidak berusaha mengajak siswa untuk berpikir, komunikasi hanya terjadi satu arah, guru biasanya menggunakan metode diskusi informasi dan diakhir pembelajaran guru memberikan latihan. Pelaksanaan model pembelajaran TGT terdiri 5 komponen yaitu presentasi kelas, tim, game, turnamen, dan rekognisi tim (Slavin, 2011: 163). Menurut Shoimin (2014:203) menyatakan TGT adalah model pembelajaran kooperatif yang mudah diterapkan, melibatkan aktivitas seluruh siswa tanpa harus ada perbedaan status, melibatkan peran siswa sebagai tutor sebaya dan mengandung unsur permainan dan reinforcement. Proses belajar peserta didik dan proses mengajar guru merupakan keterpaduan yang memerlukan pengaturan dan perencanaan yang seksama sehingga menimbulkan minat belajar peserta didik. Minat belajar peserta didik akan dapat tumbuh dan terpelihara apabila proses mengajar guru dilaksanakan secara bervariasi, antara lain dengan bantuan alat peraga. Alat peraga dapat dimasukkan sebagai bahan pembelajaran apabila alat peraga tersebut merupakan desain materi pelajaran yang diperuntukkan sebagai bahan pembelajaran.

Berdasarkan uraian masalah di atas, maka peneliti melakukan penelitian yang berjudul Pembelajaran Materi Sistem Periodik Unsur Menggunakan TGT (Team Games Tournament) Berbantukan Alat Peraga Terhadap Hasil Belajar Di Kelas X SMA UISU Medan.

\section{METODE PENELITIAN}

Metode penelitian yang digunakan adalah Quasi Experimental Design dengan one group pretestposttest. Menururt Sugiyono (2012 : 110) one group pretest-posttes adalah suatu teknik untuk mengetahui efek sebelum dan sesudah pemberian perlakuan. Dalam penelititan ini hanya menggunakan satu objek penelitian yaitu kelas eksperimen tanpa ada kelas kontrol sebagai pembading. Populasi dalam penelitian 
ini adalah seluruh siswa kelas X SMA UISU Medan. yang terdiri dari dua kelas yaitu X IPA dan X IPS dengan jumlah siswa 68 siswa. Data populasi dalam penelitian ini sebagai berikut.

Tabel 1. Data Siswa Kelas X SMA UISU Medan

\begin{tabular}{lcc}
\hline No. & Kelas & Jumlah \\
\hline 1. & X IPA & 33 \\
2. & X IPS & 35 \\
\hline & Jumlah & 68 \\
\hline & & Sumber $:$ SMA UISU Medan
\end{tabular}

Teknik pengambilan sampel pada penelitian ini adalah sampel purposiv (purposive sampling). Menurut Wijaya (2016:21) purposive sampling teknik pengambilan sampel berdasarkan karakteristik tertentu. Istrumen penelitian digunakan untuk mengukur fenomena alam maupun sosial yang diamati. Instrumen yang digunakan dalam penelitian ini adalah instrument perangkat pembelajaran dan instrument pengumpulan data. Tes yang diberikan ada dua yaitu pre-test dan post-test.

Teknik analisis data yang digunakan adalah:

a. Mencari mean dari pre- test dan post- test dengan rumus:

$$
\bar{X}=\frac{\sum x}{n}
$$

Keterangan :

$\sum X=$ jumlah data $\mathrm{x}$

$\mathrm{n}=$ sampel

\section{b. Analisis Uji T}

Uji gain dilakukan untuk mengetahui peningkatan antara nilai pretest dan posttest. Rumus n-Gain menurut Melzer sebagai berikut:

Uji ini juga dilakukan menggunakan rumus sebagai berikut:

$\mathrm{t}_{\text {hitung }}=\frac{\overline{x_{1}}-\overline{x_{2}}}{\sqrt[s]{\frac{1}{n_{1}}+\frac{1}{n_{2}}}}$

keterangan:

$\overline{x_{1}}=$ rata-rata sampel 1

$\overline{x_{2}}=$ rata-rata sampel 2

$\mathrm{s}=$ simpangan baku

$n_{1}=$ jumlah sampel 1

$n_{2}=$ jumlah sampel 2

Adapun hipotesa yang diajukan pada penelitian ini adalah sebagai berikut:

1. $\mathrm{H}_{0}$ : Tidak ada pengaruh TGT dengan menggunakan alat peraga terhadap materi sistem periodik unsur

2. $\mathrm{H}_{\mathrm{a}}$ : Terdapat pengaruh TGT dengan menggunakan alat peraga terhadap materi sistem periodik unsur 


\section{HASIL DAN PEMBAHASAN}

\subsection{Hasil Penelian}

Dari Analisis Data Penelitian yang dilakukan pada kelas X IPA diperoleh bahwa:

a. Hasil belajar Kelas Eksperimen

Hasil eksperimen di ambil setelah melakukan treatment model team games tournament dengan alat peraga di kelas X IPA sehingga 33 siswa di kelas X IPA diperoleh hasil belajarnya. Hasil pretest dan posttest penelitian kelas eksperimen dapat dilihat dilampiran 7.

Tabel 2. Pre Test dan Post Test Penelitian Kelas Eksperimen

\begin{tabular}{ccc}
\hline Kelas Eksperimen & pretest & postest \\
\hline & $\mathrm{X}_{1}$ & $\mathrm{X}_{1}$ \\
$\Sigma X$ & 1.130 & 2.655 \\
$\bar{X}$ & 34,242424 & 80,454545 \\
\hline
\end{tabular}

Berdasarkan Tabel di diatas, dapat dilihat dari 33 siswa yang telas diuji dengan pretest dan pretest didapatkan bahwa jumlah total nilai yang didapatkan oleh siswa pada pretest adalah sebesar 1130 dengan rata-rata nilai sebesar 34,24. Sedangkan jika dilihat dari hasil posttest siswa jumlah total nilai siswa adalah sebesar 2.655 dengan rata-rata nilai sebesar 80,45. Sehingga dapat dikatakan bahwa terjadi peningkatan hasil belajar yang signifikan yang dialami oleh siswa setelah menggunkan TGT berbantuan alat peraga pada materi Sistem Periodik Unsur. Untuk melihat lebih jelas perbandingan antara pretest dan posttest dapat dilihat pada grafik dibawah ini.

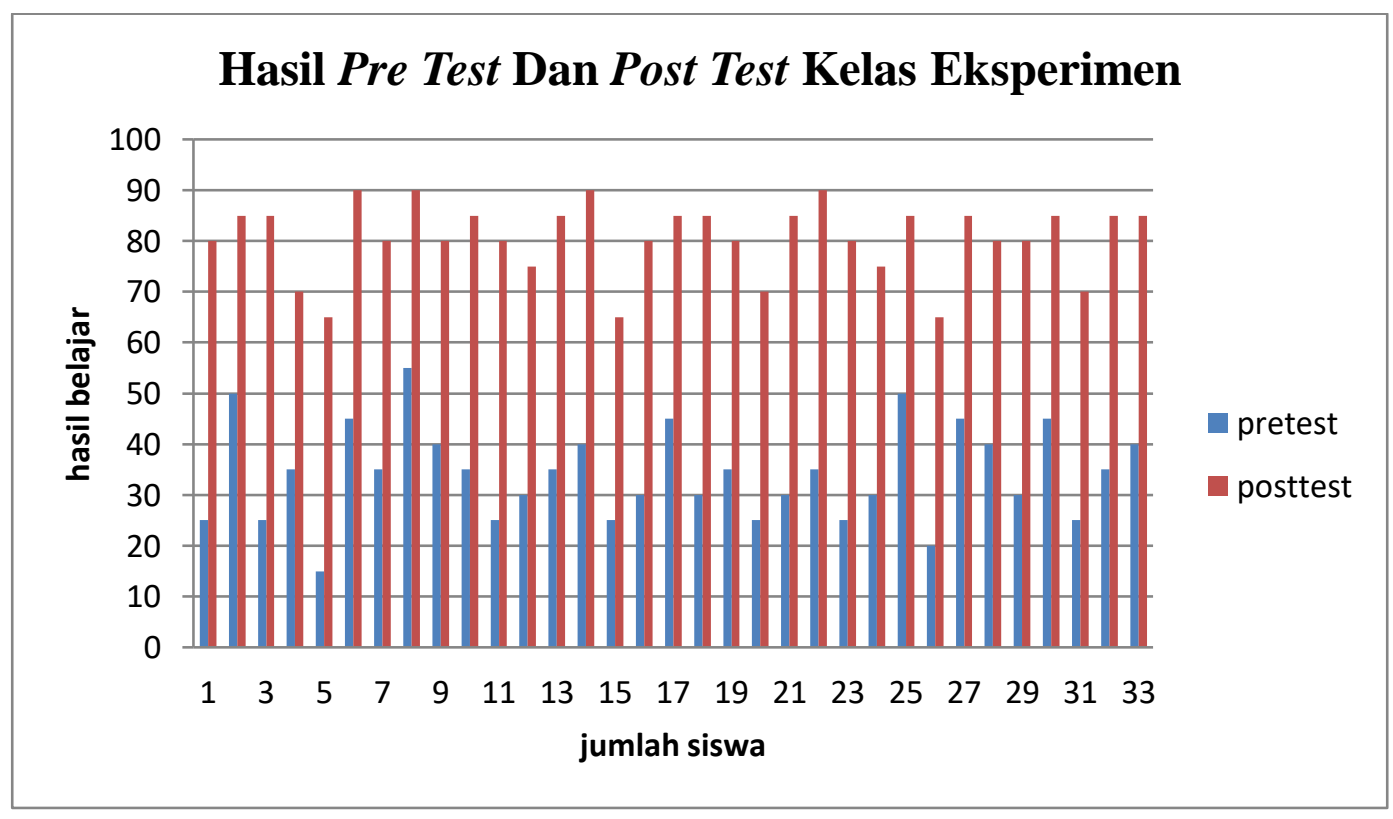




\section{Gambar 1. Perbandingan Hasil Pre-Test Dan Post Test Kelas Eksperimen}

Berdasarkan gambar di diatas, dapat dilihat bahwa terjadi peningkatan nilai yang signifikan antara pretest dan posttes pada kelas eksperimen.

\section{b. Rata-Rata Nilai Hasil Penelitian}

Hasil penelitian ini telah diperoleh dan dianalisis secara statistik. Pada penelitian ini telah diperoleh hasil rata-rata nilai hasil belajar kelas eksperimen dan kelas kontrol sebagai berikut:

Tabel 3. Rata-Rata Nilai Siswa

\begin{tabular}{cc}
\hline Rata-Rata & Eksperimen \\
\hline Pre-test & 34,24 \\
Post-test & 80,45 \\
\hline
\end{tabular}

Berdasarkan Tabel di diatas, dapat dilihat bahwa nilai pretest pada kelas eksperimen memiliki nilai rata-rata sebesar 34,24. Sedangkan nilai posttest pada kelas eksperimen sebesar 80,45 Jadi dapat disimpulkan bahwa nilai hasil belajar kelas eksperimen yang menggunakan TGT berbantuan alat peraga dapat meningkatkan hasil belajar siswa.

\section{c. Uji Hipotesis}

Data yang digunakan dalam uji hipotesis ini adalah data post-test dari kelompok sampel. Pengujian hipotesis dalam penelitian ini menggunakan uji t dengan rumus sebagai berikut:

$\mathrm{t}_{\text {hitung }}=\frac{\overline{x_{1}}-\overline{x_{2}}}{\sqrt[s]{\frac{1}{n_{1}}+\frac{1}{n_{2}}}}$

dari hasil penelitian yang telah dikakukan didapatkan data sebagai berikut:

Tabel 4 Uji Hipotesis Pretest dan Posttest

\begin{tabular}{ccccc}
\hline Jumlah siswa & Rata-rata & Varians & & $\mathrm{T}_{\text {hitung }}$ \\
\hline & & $\mathrm{S}^{2}$ & $\mathrm{~S}$ & \\
33 & 80,45 & 53,69 & 7,33 & 4,54 \\
\hline
\end{tabular}

Dari hasil perhitungan di atas terlihat bahwa $\mathrm{t}_{\text {hitung }}$ sebesar 4,54 dan $\mathrm{t}_{\text {tabel }}$ sebesar 1,669 pada taraf signifikan $5 \%$ atau $\alpha=0,05$. Karena $t_{\text {hitung }}>\mathrm{t}_{\text {tabel }}(4,54>1,669)$, maka hipotesis alternatif penelitian $\left(\mathrm{H}_{\mathrm{a}}\right)$ diterima yang berarti bahwa Ha : Terdapat pengaruh TGT dengan menggunakan alat peraga terhadap materi sistem periodik unsur.

\subsection{Pembahasan}

Dari hasil penelitian yang telah dilakukan sebanyak dua kali yaitu pretest dan posttest pada kelas eksperimen dapat dilihat bahwa $\mathrm{t}_{\text {hitung }}$ sebesar 4,54 dan $\mathrm{t}_{\text {tabel }}$ sebesar 1,669 pada taraf signifikan $5 \%$ atau $\alpha=$ 0,05 . Karena $\mathrm{t}_{\text {hitung }}>\mathrm{t}_{\text {tabel }}(4,54>1,669), \mathrm{m}$ aka hipotesis alternatif penelitian $\left(\mathrm{H}_{\mathrm{a}}\right)$ diterima yang berarti 
bahwa Ha : Terdapat pengaruh TGT dengan menggunakan alat peraga terhadap materi sistem periodik unsur.

Berdasarkan hasil analisis data yang telah dilakukan didapatkan bahwa terjadi peningkatan yang signifikan dari kelas eksperimen yaitu dengan nilai rata-rata posttest siswa adalah sebesar 80,45. Peningkatan hasil belajar ini dilihat dari hasil perbandingan Antara pretest atau tes awal yang telah diberikan kepada kelas eksperimen dengan posttest atau tes akhir yang diberikan kepada siswa, dimana untuk nilai pretest nya hanya sebesar 34,24 sedangkan posttest nya menjadi 80,45 . Dari hasil penelitian tersebut didapatkan nilai rata-rata peningkatan hasil belajar siswa sekitar 70,3\%, tetapi tidak seluruh siswa mendapatkan nilai sesuai yang di harapkan, masih ada beberapa siswa yang mendapatkan nilai dibawah KKM yaitu sekitar $18,18 \%$.

Kemudian didapatkan juga uji hipotesa atau uji $\mathrm{T}$ dengan nilai sebesar 4,54 dimana nilai uji $\mathrm{T}$ yang di dapatkan lebih besar dari pada t table. Jadi sesuai dengan hipotesa yang telah dijabarkan sebelumnya dapat dinyatakan bahwa hipotesa diterima atau Ha dapat diterima dan Ho ditolak sehingga ada pengaruh TGT dengan menggunakan alat peraga materi sistem periodik unsur.

Peningkatan nilai hasil belajar ini sendiri terjadi karena siswa sangat antusias dalam belajar sistem periodik unsur dengan menggunakan TGT berbantuan alat peraga. Dengan adanya alat peraga ini siswa menjadi lebih aktif dan bersemangat saat proses pembelajaran berlangsung, hal inilah yang mengakibatkan peningkatan signifikan hasil belajar siswa. Hal ini juga sesuai dengan pendapat sudjana (2010 : 70) bahwa alat peraga adalah alat yang dapat membantu untuk mendidik atau mengajar supaya apa yang diajarkan mudah dimengerti oleh anak didik, dengan adanya alat bantu peraga ini menyebabkan peserta didik lebih mudah dalam mempelajari dan menghafal sistem periodik unsur sehingga siswa lebih bersemangat saat proses pembelajaran tengah berlangsung. Peningkatan keaktifan siswa saat proses pembelajar dengan menggunakan alat peraga juga diperkuat dengan pendapat sadiman (2011: 71) tentang kegunaankegunaan media pembelajaran atau alat peraga salah satunya adalah dengan penggunaan media pembelajaran atau alat peraga pembelajaran yang tepat dan bervariasi dapat mengatasi sikap pasif siswa, sehingga siswa menjadi lebih aktif saat proses pembelajaran .

\section{KESIMPULAN DAN SARAN}

\subsection{Simpulan}

Berdasarkan data hasil penelitian yang telah dilakukan di SMA UISU Medan mengenai Pembelajaran Materi Sistem Periodik Unsur Menggunakan TGT (Team Games Tournament) Berbantukan Alat Peraga Terhadap Hasil Belajar dapat ditarik kesimpulan bahwa terjadi peningkatan atau perubahan hasil belajar yang signifikan yang terjadi dikelas eksperimen menggunakan menggunakan alat peraga sistem periodik unsur dimana hasil rata-rata pretes yang didapatkan siswa sebelum menggunakan TGT berbantuan alat peraga adalah sebesar 34,24 dan setelah diberi perlakuan menggunakan TGT berbantuan alat peraga hasil posttest menjadi 80,45 . Kemudia jika dilihat dari hasil uji hipotesa atau uji $\mathrm{t}$ yang telah dilakukan dikelas eksperimen didapatkan bahwa nilai uji t adalah sebesar 4,54 dan thitung lebih besar dari t tabel sehingga Ha diterima dan Ho ditolak.

\subsection{Saran}

Saran dalam penelitian ini adalah :

1. Kepada guru untuk meningkatkan kualitas mengajar dengan menerapkan metode pembelajaran yang sesuai dengan materi pembelajaran salah satunya adalah model TGT (Team Games Tournament).

2. Kepada kepala sekolah agar mampu memotivasi guru dalam meningkatkan kualitas mengajar. 


\section{DAFTAR PUSTAKA}

Candri, C.W. (2016). Upaya Meningkatkan Hasil Belajar IPA. Jurnal Pelita Pendidikan Vol. 4 Hal:124134.

Nana, S. 2010. Cara Belajar Siswa Aktif dalam Proses Belajar Mengajar. Bandung: Sinar Baru Algensindo.

Nana, S. 2017. Penilaian Hasil Proses Belajar Mengajar. Bandung: PT Remaja Rosdakarya.

Slavin, E.R. 2011. Cooperative Learning Teori Riset dan Praktik. Bandung ; Nusa Media.

Sadiman, A.M. 2011. Interaksi dan Motivasi Belajar Mengajar. Jakarta: Rajawali Press.

Sugiyono. 2012. Metode Penelitian Pendidikan Pendekatan Kuantitatif, Kualitatif, dan R\&D. Bandung: Alfabeta.

Shoimin, A. 2014. 68 Model Pembelajaran dalam Kurikulum 2013. Yogyakarta:Ar-Ruzz Media. 